\title{
Analytical tools for economic research of small municipalities and gaming techniques for community involvement (the case of Voronezh region in Russia)
}

\author{
M.I. Solosina ${ }^{1} \bowtie$, I.N. Shchepina ${ }^{1,2}$ \\ ${ }^{1}$ Voronezh State University, Voronezh, Russia; e-mail: maria.solosina@gmail.com \\ ${ }^{2}$ CEMIRAS, Moscow, Russia
}

\begin{abstract}
Relevance. The article deals with the issues of strategic territorial development in Russian regions and municipalities and the analytical tools for studying them. While there is a diversity of tools for studying large municipalities, the choice of tools for smaller urban and rural settlements is quite limited. This is the research gap this study seeks to address. Research objective. This study focuses on the case of municipal districts and settlements in Voronezh region. The aim is to show how the proposed methodology can be applied for such cases. Data and methods. The study relies on the methods of systemic analysis and synthesis, comparison and generalization, multidimensional statistics as well as on the use of gaming techniques. The data for the analysis were obtained from federal, regional and municipal statistics; municipal information systems of settlements of Voronezh region; municipal information system MISS 'Volost'; and from the executive authorities of Voronezh region. Results. The analysis of the set of indicators, including the municipal product to GRP, for the period between 2006 and 2015 has shown that the town of Liski is one of the leading municipalities in Voronezh district (the municipal product of Liskinsky accounts for over 5\% of the region's GRP). We also applied our gaming technique to establish communication between the authorities and local communities in developing the project for creation of a historical and archeological park in the settlement of Kostenki in Voronezh region. Conclusions. The proposed methodology can be quite productive in building socio-economic profiles of small municipalities, comparing them with others and revealing the interrelations between them. The gaming techniques are effective for enhancing the involvement of local communities in municipal strategic planning.
\end{abstract}

\section{KEYWORDS}

analytical tools, gaming techniques, strategic territorial development, municipality, systemic approach

\section{FOR CITATION}

Solosina, M.I., Shchepina, I.N. (2020) Analytical tools for economic research of small municipalities and gaming techniques for community involvement (the case of Voronezh region in Russia). R-economy, 6(2), 111-124. doi: 10.15826/recon.2020.6.2.010

\section{Аналитические инструменты экономических исследований малых муниципалитетов и игровые техники для вовлечения общественности (пример Воронежской области в России)}

\author{
М.И. Солосина ${ }^{1} \bowtie$, И.Н. Щепина ${ }^{1,2}$ \\ ${ }^{1}$ Воронежский государственный университет, Воронеж, Poсcия; e-mail: maria.solosina@gmail.com \\ ${ }^{2}$ Центральный экономико-математический институт Российской академии наук, Москва, Россия
}

\section{АННОТАЦИЯ}

Актуальность. В статье рассматриваются вопросы стратегического территориального развития российских регионов и муниципалитетов и аналитические инструменты для их изучения. Хотя существует множество инструментов для изучения крупных муниципалитетов, выбор инструментов для небольших городских и сельских поселений весьма ограничен. Это пробел в исследованиях, на устранение которого нацелено это исследование. Цель исследования. Данное исследование рассматривает муниципальные районы и поселки в Воронежской области. Цель состоит в том, чтобы на их примерах показать применение предложенной методологии. Данные и методы. Исследование опирается на методы системного анализа и синтеза, сравнения и обобщения, многомерного статистического анализа, а также на использование игровых технологий. Данные для анализа были получены из федеральной, региональной и муниципальной статистики; муниципальные информационные системы населенных пунктов (c) Solosina, M.I., Shchepina, I.N., 2020
\end{abstract}

\section{КЛЮЧЕВЫЕ СЛОВА}

аналитический инструментарий, организационные механизмы, стратегическое территориальное развитие, муниципалитет, системный подход 
Воронежской области; муниципальная информационная система МИСС «Волость»; и от органов исполнительной власти Воронежской области. Результаты. Анализ набора показателей, включая муниципальный продукт к ВРП, за период с 2006 по 2015 г. показал, что город Лиски является одним из ведущих муниципальных образований в Воронежской области (муниципальный продукт Лискинского района составляет более 5\% ВРП региона). Мы также применили организационный игровой механизм для установления связи между властями и местными сообществами при разработке проекта создания историко-археологического парка в поселке Костенки Воронежской области. Выводы. Предложенная методология может быть весьма продуктивной для построения социально-экономических профилей малых муниципальных образований, сравнения их с другими и выявления взаимосвязей между ними. Игровые технологии эффективны для повышения вовлеченности местных сообществ в муниципальное стратегическое планирование.

\section{Introduction}

Strategic planning has now become essential for settlements, towns, cities and other territorial entities as they get involved into the global competition for development resources (investment, human capital, technologies, etc.). Strategic plans and similar documents should incorporate the vision and aspirations of local communities. These documents should also be based on comprehensive analysis of the current situation and development prospects of the territorial unit, including its strengths and weaknesses and development priorities.

In Russia, the system of strategic territorial planning has been developing intensively over the past 15 years. One of the significant stages was Federal Law No. 172 'On Strategic Planning in the Russian Federation' adopted in 2014. The law requires methodological uniformity of such documents on the regional and municipal levels, as well as their consistency with the state strategy for economic and social development. To devise such strategies, it is necessary to conduct preliminary quantitative analysis of the statistics characterizing the socio-economic situation and development trends of the territory. National, regional and municipal-level documents are usually drawn based on federal and regional statistics, while for smaller municipalities (urban and rural settlements), this can be a problem due to the lack of statistical data. This problem can be addressed through the expansion of the database and development of tools of regional and municipal statistics.

The lack of data in the official statistics database (Russian Federal State Statistic Service Rosstat) causes a shortage of available tools for analyzing the socio-economic situation in small municipalities. For our research, we used alterna- tive resources, such as the municipal information system MISS 'Volost' and the data provided by the executive authorities of Voronezh region (Department of Economic Development, Department of communications, Department for the Development of Municipalities of Voronezh region). As a result, we were able to create our own research database.

Since there are more than 22,000 municipalities in Russia, and only in 15 of them the population exceeds one million, the available tools for studying urban and rural settlements often prove ineffective in the Russian context. For example, more than a half of inhabitants of Voronezh region live in the municipalities (446 urban and rural settlements of Voronezh region) selected for our empirical analysis. To measure the socio-economic parameters in these municipalities, we need appropriate tools that would also help us make adequate comparisons.

An important factor and the main resource for the development of settlements is human capital. The strategic nature of the social system (settlement, city, country) determines its readiness for dynamic changes and development (Arshinov, 2007). Some territories may turn out to be more attractive to people than others due to the opportunities they offer, which inevitably affects migration trends (Tiebout, 1956).

The article describes a set of analytical tools that could be used for building socio-economic profile of small municipalities (urban and rural settlements) and gaming techniques for creating projects of strategic territorial development involving local communities.

Questions of territorial strategic development are discussed by Glazyrin (2016), Glazychev (2005), Zubarevich (2010), Makarov (2010), and Pilyasov (2016). Ayvazyan, Afanasyev, Kudrov 
(2016, 2018) give particular attention to these questions on the regional level. Most studies, however, focus on territorial strategic development on the national and regional levels, some also consider the level of municipal districts, but little is said about smaller settlements. The 2009 World Bank Report 'A New Look at Economic Geography' (2009) discusses the growth points of a territory in regional and global economies and ways of determining them.

Socio-economic development of territories was analyzed by Lee (2000), Florida (2010), Shachar (1971), Efrat (1994), Portnov (2004), Malizia (1986), Bontje (2004), Grimm (1995), Shapero (1981). The issues related to territorial development projects involving local communities are investigated by V. E. Lepsky (2009), Vagin (2016), Kutuzov, Koveshnikova (2007), Myasnikova (2015), and Tyurin (2007).

The second part of our study discusses the use of gaming techniques for involvement of communities in municipal strategic planning and is thus based on the concept of the game. Conceptually, this part relies on the works by Huizinga (2014) and Shchedrovitsky (1981).

A significant contribution to the discussion of the theoretical and practical studies of municipal strategic management in Russia is made by such organizations as the Institute for Urban Economics Foundation, Leontief Center, Center for Strategic Research, and the network of Centers for Applied Urban Studies.

It should be noted, however, that most of the above-described economic studies dealing with the methodological problems of studying municipalities in Russia are of theoretical or descriptive character. There is a perceived need for applied research in this sphere, which is the gap that our paper seeks to address.

\section{Methodology and Data}

This study focuses on the case of Voronezh region, which comprises 446 urban and rural settlements and 32 municipal districts, excluding the city of Voronezh. The study relies on the analysis of the legal acts, including those regulating the development of municipalities; federal, regional and municipal statistics; data from municipal information systems of settlements of Voronezh region or RIAS (regional information and analytical system); data from municipal information system MISS 'Volost'; data from the executive authorities of Voronezh region (Department of Economic
Development, Department of Communications, Department for the Development of Municipalities of Voronezh region) (Bystryantseva et al., 2016).

The first part of the study uses multidimensional statistics and relies on the methods of systemic analysis and synthesis, comparison and generalization. The second part of the article describes a specific case when gaming techniques were applied to stimulate community engagement.

The methodological approach includes the following stages. At the first stage, the data are collected from various sources: Rosstat, regional and municipal statistics, municipal information systems, reports on the performance of local authorities, passports of municipalities, and so on. At the second stage, we select and cross-validate indicators and identify the typological data blocks. Finally, the socio-economic status of municipalities is assessed through the following procedure:

1. Evaluation and comparison of the indicators of the gross municipal product (GMP) (Petrykina et al., 2016).

To assess the GMP, we used the values of the average number of employees and the average monthly wage:

$$
G M P_{i}=\frac{G R P}{A E_{r}} \cdot A E_{i} \cdot \frac{A S_{i}}{A S_{r}},
$$

where $G M P_{i}$ is the gross municipal product estimate for the $i$-th municipal district; GRP, gross regional product; $A E_{r}$, the average number of employees in the region; $A E_{i}$, the average number of employees of the $i$-th municipal district; $A S_{r}$, the average monthly wage in organizations of the region; $A S_{i}$, the average monthly wage in organizations in the $i$-th municipal district.

$$
G M P_{j}=\frac{G M P_{i}}{A E_{i}} \cdot A E_{j} \cdot \frac{A S_{j}}{A S_{i}},
$$

where $G M P_{j}$ is the gross municipal product estimate for the $j$-th settlement; $G M P_{i}$ is the assessment of the GMP of the $i$-th district; $A E_{i}$, the average number of employees of the $i$-th municipal district; $A E_{i}$, the average number of employees of the $j$-th settlement; $A S_{i}$, the the average monthly wage in organizations of the $i$-th municipal district; $A S_{j}$, the average monthly wage in organizations of the $j$-th settlement.

To compare the GMP at the level of urban settlements, we introduced an adjusted coefficient for calculating the GMP of urban settlements 
(Petrykina et al., 2017), due to the differences in databases: the GMP of settlements was calculated according to the data of the settlement passports while the GMP of municipal districts was calculated according to the Rosstat data.

2. Allocation of clusters of municipalities by using the methods of multivariate statistical analysis according to the following criteria: by economic specialization (in accordance with OKVED (All-Russian Classifier of Economic Activities), by the level of socio-economic development, and by the number of workers employed in various types of economic activity (Petrykina et al., 2017). A comparative analysis of the results obtained through cluster analysis (Solosina, 2019).

3. Construction and comparison of economic profiles of settlements (Solosina, 2019).

The methodology for constructing an economic profile proposed in this study includes several stages. First, a database is formed and indicators are selected for urban settlements of Voronezh region. Second, the maximum, minimum and average value for each indicator are calculated:

$$
\begin{gathered}
x_{j}^{\max }=\max _{i} x_{i j}, j=\overline{1, n} ; \\
x_{j}^{\min }=\min _{i} x_{i j}, j=\overline{1, n} ; \\
\overline{x_{j}}=\sum_{i=1}^{m} \frac{x_{i j}}{m},
\end{gathered}
$$

where $j$ is the number of the indicator, $i$ is the number of the city settlement, $x_{i j}$ is the value of the indicator.
Third, the average value is taken as the comparison base, equal to $100 \%$ or 1 , in relation to which the levels for each indicator are calculated for each urban settlement.

$$
\begin{gathered}
z_{i j}=\frac{x_{i j}}{\overline{x_{j}}}, \quad i=\overline{1, m}, \quad j=\overline{1, n} ; \\
z_{j}^{\text {max }}=\frac{x_{j}^{\text {max }}}{\overline{x_{j}}}, \quad j=\overline{1, n} ; \\
z_{j}^{\text {min }}=\frac{x_{j}^{\text {min }}}{\overline{x_{j}}}, \quad j=\overline{1, n} ; \\
\overline{z_{j}}=1, \quad j=\overline{1, n .}
\end{gathered}
$$

The minimum and maximum values are calculated for the levels relative to the average for each indicator.

Finally, for each urban settlement, a diagram of the scatter of values for each indicator is built. At the same time, two graphs are plotted on the chart: average values and indicator values for the given settlement. The resulting diagram represents the economic profile of the given settlement (Fig. 1).

Another key aspect of our research methodology is the focus on the organizational mechanism - system-social design methodology (SSD) (Solosina, 2019), which has been proven effective for engaging members of local communities in strategic territorial development. This is a communicational method aimed at involving people in the process of strategic planning and implementation of strategic documents.

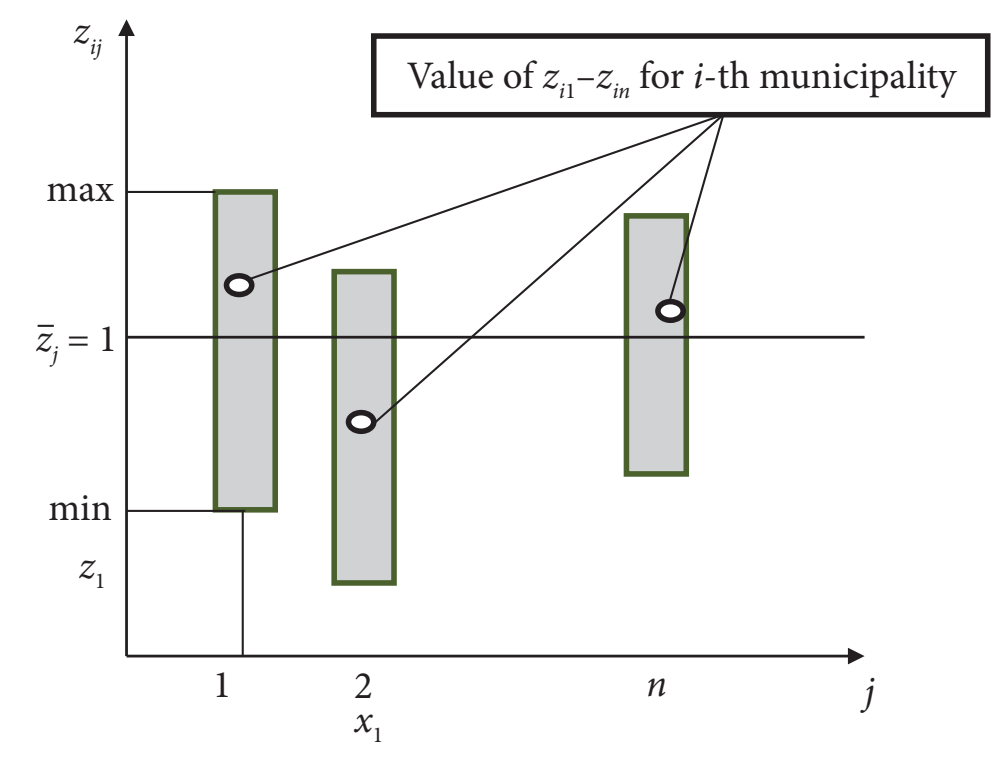

Figure 1. Economic profile of a settlement 
There are two approaches to the process of strategic development at the municipal level: 'administrative-expert' and 'partner' (Solosina \& Schepina, 2016). A distinctive feature of the latter approach is the involvement of residents in the process of strategic decision-making and development of appropriate tools for doing so. Members of local communities are involved into the strategic planning process with the help of gaming techniques.

The basis of the SSD methodology is the 'game square' method proposed by M.A. Kutuzova, which includes a series of game seminars (problem seminar / project seminar / strategic game / operational game) and developed on the basis of military operational-tactical games and organizational-activity games (the format was initially developed by G.P. Shchedrovitsky (1981)). The main stages of the game and its preparation within the SSD framework are shown in Figure 2 below.

First, the technical task for the game is agreed upon with the customer. The customer may be, for example, the municipal administration, a regional executive authority, a self-governing territorial body, an action group, or a business. After agreeing on the technical specifications, the game master and the game support team develop the scenario by conducting preliminary research and analysis.

Second, the list of participants is drawn: it is necessary to involve all the participants interested in solving the problem posed by the customer. To participate in the game, one must know the rules of the game and the terminology, which is why the preparatory materials should be sent to participants in advance.

When the game starts, the first stage is to discuss and revise the rules and terminology, which is necessary to stimulate creative thinking of the participants. Then, in accordance with the methodology, game participants go through all SSD stages such as research, situation analysis, forecasting, development of scenarios, creation of a project line, and start-up projects. Following that, the participants are transferred from the game into the real project space. At this stage, the participants discuss the future prospects of the project developed during the game. Based on the results of the game, the game report is prepared, which contains all the material that was collected and analyzed.

There are three types of game project outcomes: the game product; development of the participants' soft skills; and the network. The game product is a system-social model of the project which includes: concepts, values, project characteristics, activities, system of management and leadership, roadmap, and potential risks. Soft skills are the skills and competencies of the participants that are developed through their experience of team work. A network is here understood as an action group that creates and signs the project declaration, thereby indicating their interest in further participation.

The uniqueness of SSD lies in the gaming component, since it is the game tools that help create a common strategy for a system-social project, motivate people to join such projects and become part of project teams. The SSD methodology is focused on the creation of a system-social project and the formation of the institutional environment for creating other projects within the framework of the SSD project. Expert support at all stages allows project participants to maintain the strategic focus of the project.

\section{Results}

We applied the above-described methodological approach to assess the socio-economic status of municipalities in Russia by focusing on the case of the town of Liski in Voronezh region.

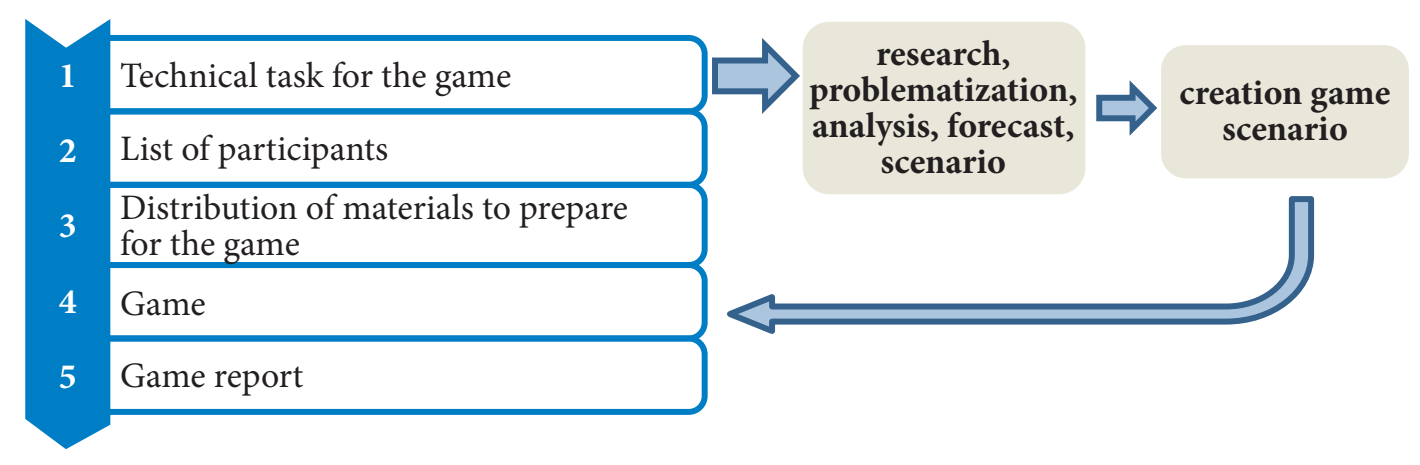

Figure 2. Stages of the game and its preparation 
In accordance with the regional plan for the development of Voronezh region, Liski is the administrative center of Liskinsky district, which in total includes 23 urban and rural settlements. Since 2013, Liskinsky district has been one of the leading municipal districts in Voronezh region, according to the results of the comprehensive assessment of the regin's socio-economic development.

We used the Rosstat data and settlement passports to obtain GMP estimates for Liskinsky municipal district for 2006, 2010 and 2015, and then for the town of Liski itself.

Let us compare the GMP values of Liskinsky municipal district for 2006, 2010 and 2015 (see Table 1), given that the average monthly wage in Voronezh region in 2015 amounted to 27,772.7 rubles, GRP was $823,133.6$ million rubles, the average number of employees was 500,356. The GMP was just over 5\% of the region's GRP. Since 2006, Liskinsky municipal district, along with Rossoshansky municipal district and Borisoglebsky city district, has been among the three leading municipalities in terms of GMP (Table 1).

Table 1

The GMP of Liskinsky municipal district in 2006, 2010 and 2015

\begin{tabular}{|r|r|r|r|r|}
\hline Year & $\begin{array}{c}\text { Average num- } \\
\text { ber of employ- } \\
\text { ees, people }\end{array}$ & $\begin{array}{c}\text { Average } \\
\text { monthly } \\
\text { wage, rub }\end{array}$ & $\begin{array}{c}\text { GMP, mln } \\
\text { rub }\end{array}$ & $\begin{array}{c}\text { GMP } \\
\text { in \% to } \\
\text { GRP }\end{array}$ \\
\hline 2006 & 29,870 & $7,773.7$ & $8,908.05$ & 5.36 \\
\hline 2010 & 27,651 & $15,181.3$ & $17,933.96$ & 5.17 \\
\hline 2015 & 26,247 & $26,571.0$ & $41,310.52$ & 5.02 \\
\hline \multicolumn{3}{|c|}{ Source: compiled by the authors. } \\
\hline
\end{tabular}

After evaluating the general indicator of socio-economic development - the GMP at the district and settlement levels, we identifed the typological group of this municipality. To do this, we used cluster analysis (Tables 2, 3). In 2015, according to the results of clustering in terms of socio-economic development, Liskinsky municipal district belonged to cluster A together with Rossoshansky, Pavlovsky, Novousmansky municipal areas and Borisoglebsky municipal districts. In terms of economic specialization, the areas like Pavlovsky, Novousmansky, Bobrovsky, Kalacheevsky, Ostrogozhsky, and Talovsky municipal districts belong to cluster 2 (Table 2) - the leading cluster in terms of crop and livestock production. At the same time, the town of Liski ranks second in terms of the volume of production (works and services) in such types of economic activities as "Production and distribution of electricity, gas and water" and "Manufacturing". Thus, the municipalities in this cluster can be characterized as "agricultural leaders", although they also have a fairly well developed sphere of industrial production (Table 3 ).

In each column of Table 2, the leading municipalities are highlighted in orange. Those municipalities that rank second after the leaders are highlighted in yellow. These two groups include municipalities with the following characteristics:

- clustering: a combination of clusters A - 1 and A - 2 (for both groups);

- gross municipal product (GMP): more than $2 \%$ of GRP (orange group) and 1-2\% of GRP (yellow group);

- population: over 70,000 (orange group) and 40,000-70,000 (yellow group);

- wages: more than 25,000 rubles (for both groups).

Other colors highlight the groups of municipalities that have the same types in two clusters.

Next, we turn to the adjusted estimate of the GMP obtained for some urban settlements of Voronezh region in 2015, including Liski (Table 3). Liski is the leader in terms of the GMP $(22,241.72$ million rubles), followed by Rossosh $(18,425.98$ million rubles).

As for the number of employees and type of activity (Table 3), Liski, along with Rossosh, belongs to cluster 1 with a high number of employees in "Manufacturing industries" and with fairly high rates of employees in "Agriculture, hunting and forestry", "Production and distribution of electricity, gas and water." Thus, according to the selected indicators of economic specialization, the employment structure of Liski does not fully correspond to the specialization of Liskinsky municipal district. It is more industrial than in the district as a whole. The city has large enterprises manufacturing metal structures and building materials and processing agricultural products.

At the following stage, we are going to turn to the economic profile of the town of Liski and consider the town's progress during the given period (Figures 2-4).

In 2006-2015, Liski maintained the leading position in the following indicators: total number of employees; the number of employees in 'Manufacturing'; 'Transport and communications' (the town has a large railway junction and a river port); 'Agriculture, hunting and forestry'; 'Wholesale and retail trade, repair of motor vehicles, motorcycles, 
Municipal districts in Voronezh region in 2015

\begin{tabular}{|c|c|c|c|c|c|}
\hline Municipal districts & $\begin{array}{c}\text { Clusters by the level of socio-eco- } \\
\text { nomic development (A-F) }\end{array}$ & $\begin{array}{l}\text { Clusters by economic } \\
\text { specialization }(1-4)\end{array}$ & $\begin{array}{c}\text { GMP } \\
\text { in \% GRP }\end{array}$ & $\begin{array}{c}\text { Population, } \\
\text { people }\end{array}$ & Wages, rub. \\
\hline Rossoshansky & $\mathrm{A}$ & 1 & 3.74 & 93,368 & $25,571.3$ \\
\hline Borisoglebsky & A & 1 & 2.01 & 63,678 & $21,046.8$ \\
\hline Liskinsky & $\mathrm{A}$ & 2 & 5.02 & 101,764 & $26,571.0$ \\
\hline Pavlovsky & $\mathrm{A}$ & 2 & 1.70 & 55,990 & $21,476.4$ \\
\hline Novoysmansky & A & 2 & 1.52 & 79,183 & $25,594.6$ \\
\hline Semiluksky & A & 3 & 1.27 & 67,558 & $22,340.7$ \\
\hline Anninsky & $\mathrm{B}$ & 2 & 1.05 & 41,195 & $19,513.8$ \\
\hline Ramonsky & B & 3 & 1.72 & 32,440 & $25,361.3$ \\
\hline Bobrovsky & $\mathrm{C}$ & 2 & 1.23 & 49,148 & $21,004.6$ \\
\hline Kalacheevsky & $\mathrm{C}$ & 2 & 1.08 & 53,670 & $19,732.4$ \\
\hline Buturlinovsky & $\mathrm{C}$ & 3 & 0.88 & 47,918 & $18,846.2$ \\
\hline Ertilsky & $\mathrm{C}$ & 3 & 0.51 & 23,839 & $18,430.2$ \\
\hline Novohopersky & $\mathrm{C}$ & 4 & 0.71 & 38,787 & $20,119.0$ \\
\hline Bogucharsky & $\mathrm{C}$ & 4 & 0.62 & 35,732 & $19,069.6$ \\
\hline Khokholsky & $\mathrm{C}$ & 4 & 0.61 & 29,702 & $22,213.6$ \\
\hline Verhnemamonsky & $\mathrm{C}$ & 4 & 0.38 & 19,890 & $19,526.9$ \\
\hline Petropavlovsky & $\mathrm{C}$ & 4 & 0.23 & 18,103 & $20,542.5$ \\
\hline Repyevsky & $\mathrm{C}$ & 4 & 0.23 & 15,742 & $21,055.7$ \\
\hline Talovsky & $\mathrm{D}$ & 2 & 0.86 & 39,785 & $20,320.7$ \\
\hline Verkhnekhavsky & $\mathrm{D}$ & 3 & 0.65 & 24,665 & $23,856.3$ \\
\hline Kashirsky & $\mathrm{D}$ & 3 & 0.49 & 24,343 & $23,979.1$ \\
\hline Ternovsky & $\mathrm{D}$ & 3 & 0.36 & 19,824 & $18,791.5$ \\
\hline Vorobyevsky & $\mathrm{D}$ & 3 & 0.33 & 17,071 & $19,239.2$ \\
\hline Podgorensky & $\mathrm{D}$ & 4 & 0.54 & 25,338 & $20,726.4$ \\
\hline Nizhnedevitsky & $\mathrm{E}$ & 4 & 0.40 & 18,989 & $24,963.0$ \\
\hline Ostrogozhsky & $\mathrm{F}$ & 2 & 1.51 & 58,950 & $23,236.9$ \\
\hline Gribanovsky & $\mathrm{F}$ & 2 & 0.74 & 31,100 & $21,096.1$ \\
\hline Kantemirovsky & $\mathrm{F}$ & 3 & 0.85 & 34,923 & $21,898.2$ \\
\hline Paninsky & $\mathrm{F}$ & 3 & 0.54 & 26,531 & $19,435.3$ \\
\hline Povorinsky & $\mathrm{F}$ & 4 & 0.60 & 32,755 & $21,014.2$ \\
\hline Olkhovatsky & $\mathrm{F}$ & 4 & 0.54 & 23,356 & $20,585.7$ \\
\hline Kamensky & $\mathrm{F}$ & 4 & 0.48 & 18,921 & $22,470.7$ \\
\hline
\end{tabular}

Source: compiled by the authors.

Table 3

Urban settlements in Voronezh region in 2015

\begin{tabular}{|c|c|c|c|c|c|c|c|}
\hline & $\begin{array}{c}\text { Clusters in } \\
\text { terms of so- } \\
\text { cio-economics } \\
\text { development }\end{array}$ & $\begin{array}{l}\text { Economy: Cluster spe- } \\
\text { cialization }(1-4)\end{array}$ & & $\begin{array}{l}\text { lusters of mu- } \\
\text { nicipalities }\end{array}$ & $\begin{array}{c}\text { GMP adjusted } \\
\text { for settle- } \\
\text { ments' GMP, } \\
\text { million rub. }\end{array}$ & $\begin{array}{l}\text { Popula- } \\
\text { tion }\end{array}$ & Wage, rub \\
\hline Rossosh & $\mathrm{A}$ & 1 industrial & 1 & industrial & $18,425.98$ & 62,688 & 22,776 \\
\hline Liski & A & 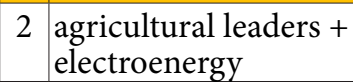 & 1 & industrial & $22,241.72$ & 54,788 & 26,572 \\
\hline Pavlovsk & A & $2 \begin{array}{l}\text { agricultural leaders + } \\
\text { electroenergy }\end{array}$ & 4 & with low rates & $6,426.22$ & 25,081 & 22,063 \\
\hline Davydovskoe & A & $2 \begin{array}{l}\text { agricultural leaders + } \\
\text { electroenergy }\end{array}$ & 4 & with low rates & $1,343.52$ & 5,258 & 16,725 \\
\hline Latnensky & A & \begin{tabular}{|l|l}
3 & agricultural
\end{tabular} & 4 & with low rates & $1,050.44$ & 7,359 & 20,626 \\
\hline Anninsky & B & 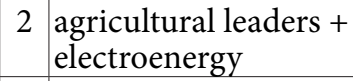 & 4 & with low rates & $3,441.91$ & 16,729 & $19,221.8$ \\
\hline Ramon & B & \begin{tabular}{|l|l} 
& agricultural \\
\end{tabular} & 4 & with low rates & $2,856.75$ & 8,381 & 19,800 \\
\hline Kalach & $\mathrm{C}$ & 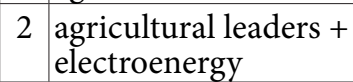 & 2 & agricultural & $1,956.36$ & 19,248 & 12,065 \\
\hline
\end{tabular}


End Table 3

\begin{tabular}{|c|c|c|c|c|c|c|c|c|}
\hline & $\begin{array}{c}\text { Clusters in } \\
\text { terms of so- } \\
\text { cio-economics } \\
\text { development }\end{array}$ & & $\begin{array}{l}\text { onomy: Cluster spe- } \\
\text { cialization }(1-4)\end{array}$ & & $\begin{array}{l}\text { usters of mu- } \\
\text { nicipalities }\end{array}$ & $\begin{array}{c}\text { GMP adjusted } \\
\text { for settle- } \\
\text { ments' GMP, } \\
\text { million rub. }\end{array}$ & $\begin{array}{l}\text { Popula- } \\
\text { tion }\end{array}$ & Wage, rub \\
\hline Bobrov & $\mathrm{C}$ & 2 & $\begin{array}{l}\text { agricultural leaders + } \\
\text { electroenergy }\end{array}$ & 4 & with low rates & $3,290.01$ & 19,956 & 16,780 \\
\hline Buturlinovka & $\mathrm{C}$ & 3 & agricultural & 2 & agricultural & $3,772.99$ & 25,230 & 18,600 \\
\hline Ertil & $\mathrm{C}$ & 3 & agricultural & 2 & agricultural & $1,904.31$ & 10,740 & 18,530 \\
\hline Kantemirovskoe & $\mathrm{C}$ & 3 & agricultural & 4 & with low rates & $1,888.86$ & 11,113 & 22,600 \\
\hline Novokhopersk & $\mathrm{C}$ & 4 & with low rates & 2 & agricultural & $2,022.34$ & 13,845 & 19,500 \\
\hline Boguchar & $\mathrm{C}$ & 4 & with low rates & 4 & with low rates & $1,446.83$ & 11,162 & 17,322 \\
\hline Khokholskoe & $\mathrm{C}$ & 4 & with low rates & 4 & with low rates & 855.34 & 7,549 & 14,916 \\
\hline Yelan-Kolenovskoe & $\mathrm{C}$ & 4 & with low rates & 4 & with low rates & 560.92 & 3,635 & 20,600 \\
\hline Nizhnekislyayskoye & $\mathrm{C}$ & 4 & with low rates & 4 & with low rates & 465.77 & 3,576 & 16,200 \\
\hline Talovskoe & $\mathrm{D}$ & 2 & $\begin{array}{l}\text { agricultural leaders + } \\
\text { electroenergy }\end{array}$ & 4 & with low rates & $1,643.26$ & 11,736 & 15,937 \\
\hline Podgorensky & $\mathrm{D}$ & 4 & with low rates & 4 & with low rates & $1,026.02$ & 5,750 & 21,004 \\
\hline Gribanovskoe & $\mathrm{F}$ & 2 & $\begin{array}{l}\text { agricultural leaders + } \\
\text { electroenergy }\end{array}$ & 2 & agricultural & $3,193.01$ & 15,255 & 22,400 \\
\hline Ostrogozhsk & $\mathrm{F}$ & 2 & $\begin{array}{l}\text { agricultural leaders + } \\
\text { electroenergy }\end{array}$ & 3 & $\begin{array}{l}\text { electrical } \\
\text { energy }\end{array}$ & $5,027.35$ & 32,944 & 16,772 \\
\hline Pereleshinskoe & $\mathrm{F}$ & 3 & agricultural & 4 & with low rates & 437.31 & 2,797 & 18,100 \\
\hline
\end{tabular}

Source: the authors' calculations based on the original dataset

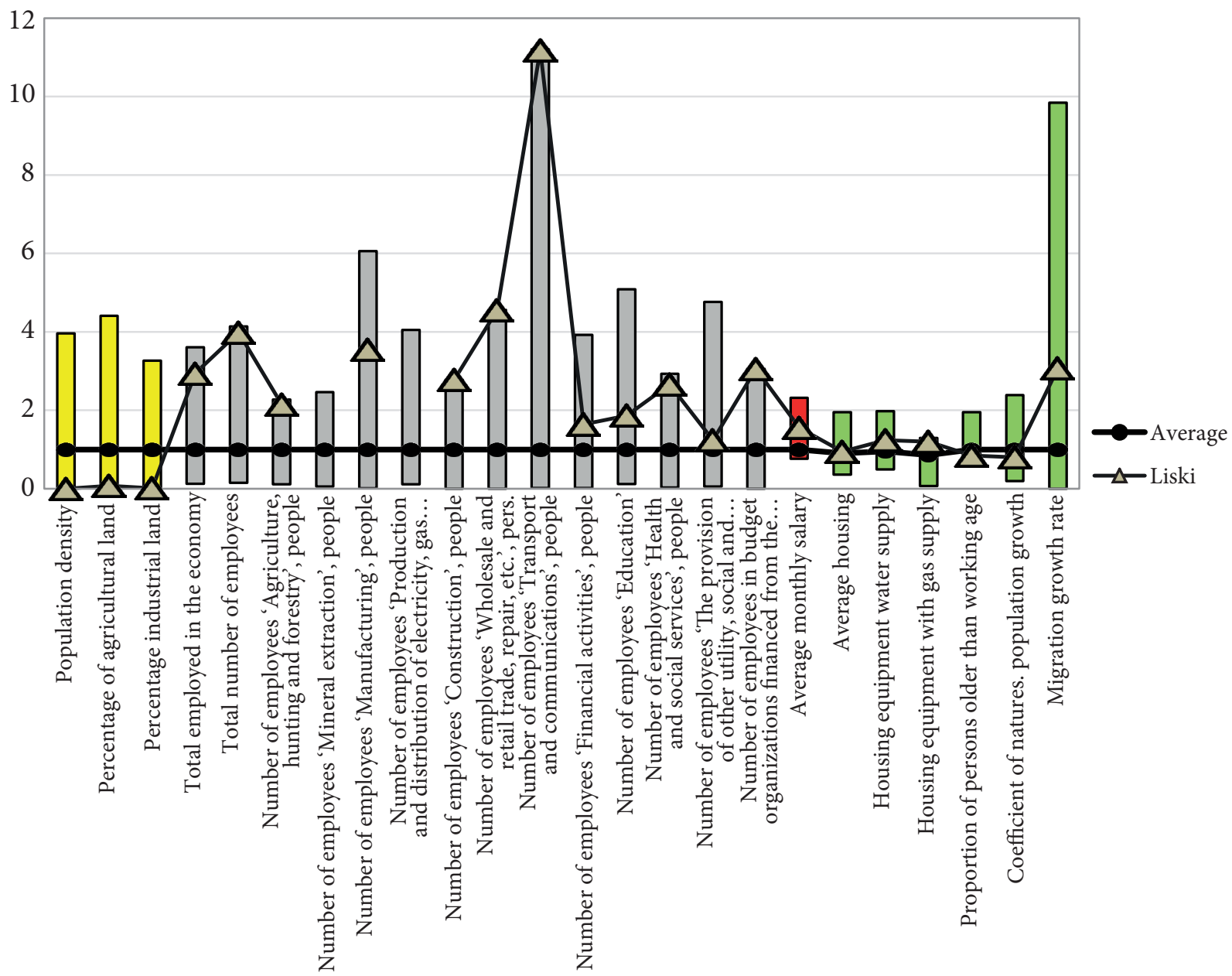

Figure 3. Economic profile of Liski for 2006

Source: the authors' calculations based on the original dataset 
household products and personal items'; 'Education' (the town has several professional colleges and branches of universities); 'Healthcare and social services'. It should be noted that we don't have the data for 2006 on such indicators as the share of industrial land and the share of agricultural land. Moreover, in 2010 and 2015, the share of industrial land reached its maximum, and the share of agricultural land, its minimum, which characterizes the city as an industrial center.

In comparison with other settlements, Liski was losing its position in terms of the number of employees in 'Construction' (even though the town is producing building materials) and 'Financial activity'. The indicators of natural and migration growth showed negative dynamics since 2010 , the population of the city decreased by $2 \%$. In the other indicators, the city retained its position (Fig. 3-5).
We believe that the proposed methodological approach and its visualization can help be used for managerial decision-making and strategic planning of municipalities.

\section{Engaging and Involving Local Communities in Municipal Strategic Planning: Gaming Techniques}

Involving people into the process of strategic planning is a key to successful implementation of municipal strategies. The proposed SSD methodology was tested in the settlement of Kostenki in 2017. Kostenki is a comparatively small settlement, located $47 \mathrm{~km}$ from the city of Voronezh. The population is 1485 people, according to the settlement's passport, aged 0-6 (45 people); 7-17 (96 people); $18-45$ (560 people); 46-59 (295 people); and 60 or older (479 people). On the territory of the settlement, there are two agricultural

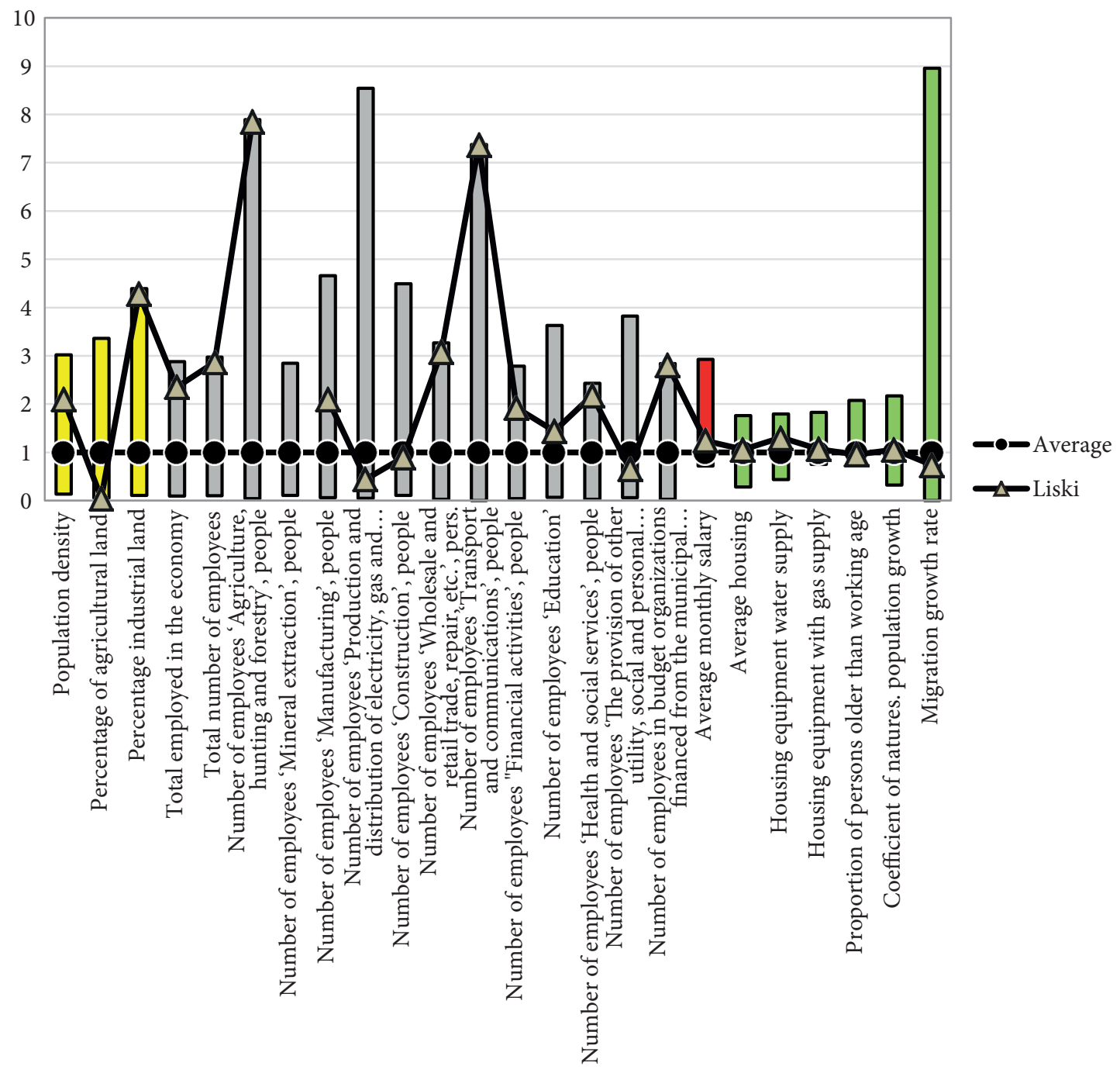

Figure 4. Economic profile of Liski for 2010 Source: the authors' calculations based on the original dataset 


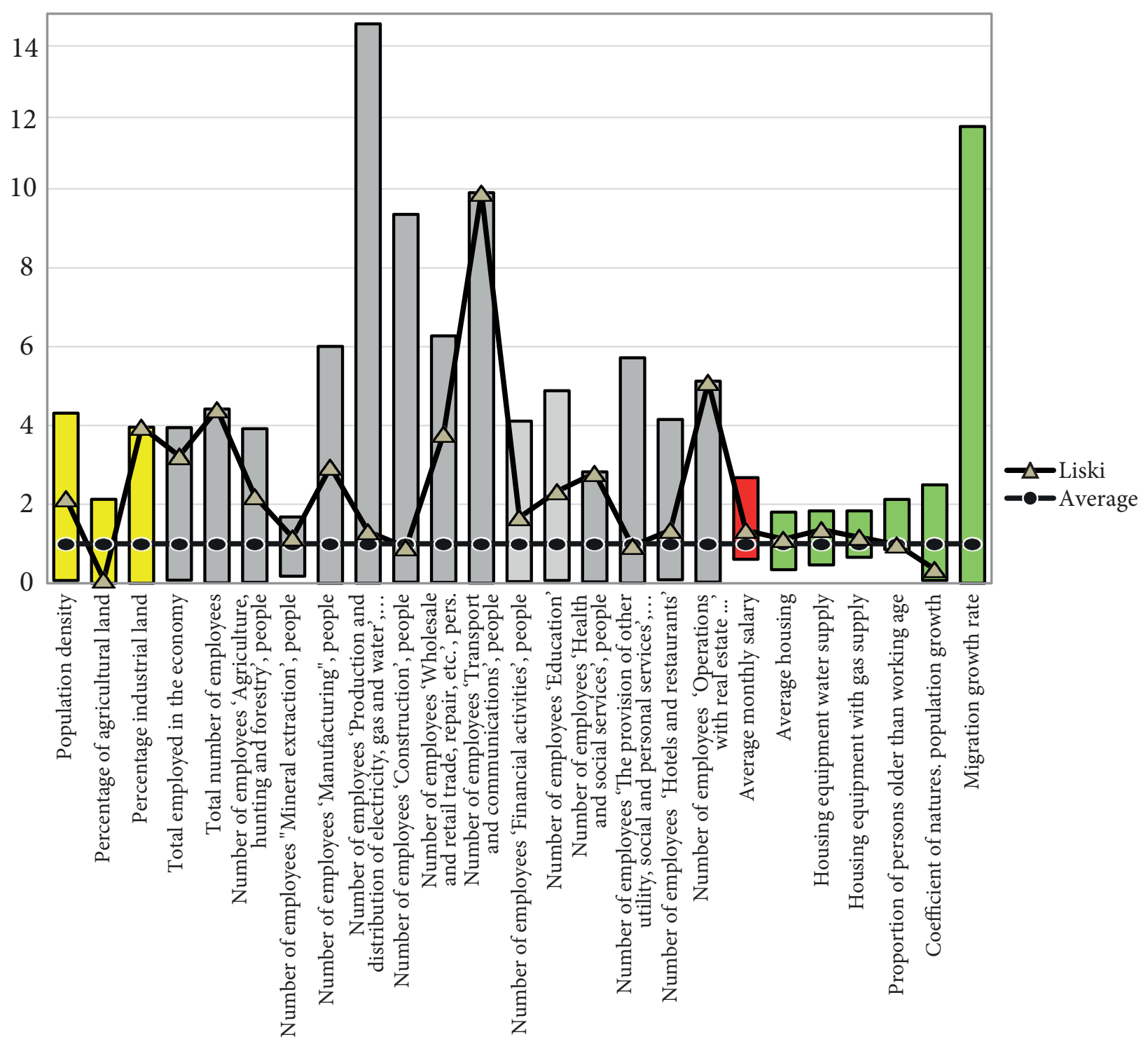

Figure 5. Economic profile of Liski for 2015

Source: the authors' calculations based on the original dataset

enterprises and 639 private farms. According to the statistics, the average monthly wage in the district in 2015 was 22,213.6 rubles, and the average wage of workers in peasant farms, 10,644 rubles. The average number of workers in peasant farms was 8 people. In total, the average number of workers (external part-timers excluded) in the district in 2015 was 3809. Kostenski rural settlement (Kostenki) is located in Khokholsky district, which has the MP of 5011.91 million rubles or $0.61 \%$ of GRP (Tables 2 and 3 ).

The settlement of Kostenki has a unique tourist potential. Kostenki is world-famous for its rich historical and cultural heritage and natural beauty. The first people settled in these places 50,000 years ago, the first dwellings date back 25,000 years, there are the cultural layers in the area that store samples of primitive art (Paleolithic Venus).

The modern village of Kostenki is the heir to the city of Kostyensk, an outpost of the $17^{\text {th }}$ century on the southern outskirts of Russia. Kostyensk constituted a part of the Belgorod system of defensive fortifications protecting the local communities from Tatar raids from the south. Then, with the decline of its functionality as a fortress, the city lost its status and became a rural settlement.

The customer of the game was the entrepreneur who planned to create an archeological park on the territory of Kostenki. The game was aimed at developing a SSD model for creation of such a park, devising possible scenarios for this project and a roadmap for its implementation. There were 
20 participants in the game: students, entrepreneurs, historians, journalists and economists. The key participants were the Director of the Kostenki Open-Air Museum and the customer (initiator of the project). The participants of the game belonged to various age and professional groups.

Residents of the settlement participated in a number of regional programs: for example, in 2016 the municipality received 96,000 rubles for the improvement of a children's playground and in 2017, the residents of the settlement decided to participate in the budgeting program and submitted their road repair project for the 2018 competition.

Below are the outcomes of the game, which fall within three categories: the game product, the participants' soft skills, and the network.

\section{Game product}

Participants of the game pointed out that there recently Russian people has started to take more interest in the history of their country, region, community and family, which means that the project of Kostenki may benefit from this trend. The result of the game was the participants' common vision of the future development of archeological park 'Kostenki' and the surrounding area.

1.1. System-social model of the project.

The historical and archaeological park is the result of a joint effort of the community, entrepreneurs and local authorities.

Participants of the game pointed out that free time is now becoming a key development resource for people and that archaeological park in Kostenki could follow the concept of life history, which corresponds to this trend.

The creation of an archaeological park includes the study of the types of activities that could be offered to its visitors such as educational online and off-line events involving representatives of the academia and members of local communities; amateur archeology course; expositions with augmented reality experiences; experience-based programs for tourists (e.g. experience life in the Paleolithic Age) and volunteering programs.

All types of project activities fall within the concept of leisure as time for personal development and education.

1.2. The main characteristics of the project include the following.

1.2.1. Collective decision-making mechanism and creation of an appropriate management structure. The proposed range of activities, on the one hand, makes the system more stable, on the other hand, it requires appropriate management at all stages of the project development;

1.2.2. Networking. The project, among other things, stimulates participants to build relations within the project team and interact with external stakeholders;

1.2.3. Brand development. The archeological park as a heritage project capitalizes on the site's unique location and history;

1.2.4. Rules of cooperation. The game relies on a system of rules devised by the participants themselves; participants should meet a set of requirements such as willingness to invest resources; motivation; sharing the project's values;

1.2.5. Megaproject. In order to manage several projects at once, efficient leadership and an organizational structure are necessary.

The management should include an expert council responsible for the development and implementation of the project strategy, the search for strategic partners, analysis of the project's trajectory and so on. There should also be managers responsible for specific areas and issues. In order to create such a management structure, it is necessary to distinguish between operational and strategic aspects of the project. For example, to realize a subproject aimed at organizing a series of lectures on Kostenki, it is necessary to devise a strategy, select topics, prepare materials, choose the time and place, coordinate the work of organizers, and so on. All this requires the organizational structure to be horizontal and flexible, able to quickly adapt to the changing situation.

1.3. Project risks. Certain risks, primarily of organizational nature, should be considered: for example, the loss of strategy or uniqueness of the project or disagreements between the parties involved in project realization.

2. Development of Participants' Soft Skills and the Network

For the project team, it is essential that all its participants should enhance their teamwork and other basic skills.

At the first stage of the project, a project declaration is devised and signed. The declaration is necessary to indicate the participants' commitment to the values and goals of the project. One of the significant outcomes of the game is to create an action group that would be responsible for implementation of the project in real life.

According to the SSD methodology, the participants of the game go through the following 
stages: research - analysis - forecasting - devising development scenarios - developing subprojects - start-up stage. In the game, these stages take less time than in real life, so the game prepares participants for future realization of the project and helps them develop the necessary skills.

The SSD methodology is aimed at developing a strategic territorial development project and can be used at the stages of strategy development and implementation.

\section{Conclusions}

The article proposes methodological tools for investigating socio-economic development of small municipalities and gaming techniques for involving local communities in municipal strategic planning.

The methodological approach is based on the integrated use of our original databases (Bystryantseva et al., 2016) and enables us to conduct analysis of individual municipal districts and compare them with other municipalities. We tested these tools by using the data on Voronezh region and showed the role specific municipalities (for example, the town of Liski) play in the region's socio-economic system (Solosina, Shchepina, 2016).

To make the proposed approach more effective, it could be combined with other analytical tools, for example, SWOT analysis. We could also build socio-economic profiles of municipalities to reveal their strengths and weaknesses and development trends and describe their relationships with other municipalities.

As for the SSD methodology, in general, it is aimed at developing large-scale strategic projects and at developing participants' management competencies. It is applicable both in business and in territorial development; it can also be used for educational purposes. As our experiment in the settlement of Kostenki has shown, the development and implementation of projects using SSD techniques can stimulate cooperation between businesses, authorities and local communities.

The results of this study can serve as a methodological and instrumental foundation for comprehensive regional diagnostics and improvement of the system of strategic planning and management at the municipal level.

\section{References}

Arshinov, V.I. (2007). Problems of subjects in post-non-classical science. Moscow: Kogito Center, 176.

Ayvazyan, S.A., Afanasyev, M.Yu., \& Kudrov, A.V. (2016). The method of clustering the regions of the Russian Federation takinginto account the sectoral structure of the GRP. Applied Econometrics, 1(41), 24-46. (In Russ.)

Ayvazyan, S.A., Afanasyev, M.Yu., \& Kudrov, A.V. (2018). A method of comparing the regions of the Russian Federation according to technical efficiency estimates taking into account the structure of production. Economics and Mathematical Methods, 54(1), 43-51. (In Russ.)

Bontje, M. (2004). Facing the challenge of shrinking cities in East Germany: The case of Leipzig. GeoJournal, 61, 13-21.

Bystryantseva, D.I., Halperin, M.B., \& Schepina, I.N. (2016). A comparative analysis of municipal information systems as part of a comprehensive analysis of the development of municipalities. Modern Economics: Problems and Solutions, 11, 129-140. (In Russ.)

Efrat, E. (1994). New development towns of Israel (1948-93). Cities, 11(4), 247-252.

Florida R. (2010). The Great Reset: How New Ways of Living and Working Drive Post-Crash Prosperity, New York: HarperCollins.

Glazychev, V.L. (2005). Deep Russia: 2000-2002. Moscow: New publishing house. 328. (In Russ.)

Glazyrin, M.V. (2016). The system of sustainable development of society at the level of the municipality. Moscow: Nauka, 172. (In Russ.)

Grimm, F.D. (1995) Return to normal - Leipzig in search of its future position in Central Europe. GeoJournal, 36, 319-335.

Huizinga, J. (2014). Homo Ludens: A Study of the Play-Element in Culture. Mansfield Center, CT: Martino Publishing. 
Kutuzov, M.A., \& Koveshnikova, E.V. (2007). Regional development strategies: between a strategic breakthrough and a strategic one. Economic Strategies, 7, 26-30. Retrieved from http://www. inesnet.ru/article/regionalnye-strategii-razvitiya-mezhdu-strategicheskim-proryvom-i-strategicheskim-tupikom/ (In Russ.)

Lee Kuan Yew (2000) From Third World to First: 1965-2000: Memoirs of Lee Kuan Yew. The Singapore Story. Harper, Vol. 2, 752.

Lepsky, V.E. (2009). Subject-oriented approach to innovative development. Moscow: Kogito-center Publishing House, 208. (In Russ.)

Makarov, V.L. (2010). Social Clusterism. Russian challenges. Moscow: Business Atlas, 272. (In Russ.)

Malizia, E.E. (1986) Economic Development in Smaller Cities and Rural Areas, Journal of the American Planning Association, 52(4), 489-499.

Myasnikova, T.A. (2015). Organizational and management mechanism for local development planning based on the principles of joint management. Region: Systems, Economics, Management, 2(29), 88-96. (In Russ.)

Petrykina, I.N., Solosina, M.I., \& Schepina, I.N. (2016). On methods for assessing gross municipal product. Region: Systems, Economics, Management, 3(34), 106-113. (In Russ.)

Petrykina, I.N., Solosina, M.I., \& Schepina, I.N. (2017). The use of cluster analysis for typology of municipalities. Bulletin of the Voronezh State University. Series Economics and Management, 4, 154-164. (In Russ.)

Pilyasov, A.N. (2016). Russia's Arctic Frontier: Paradoxes of Development Regional Research of Russia, 6(3), 227-223.

Portnov, B.A. (2004). Long-term growth of small towns in Israel: Does location matter? The Annual of Regional Science, 38, 627-653.

Shachar, A. (1971). Evaluation of National Urbanization Policy. Journal of the American Institute of Planners, 37(6), 362-372.

Shapero, A. (1981). Entrepreneurship: Key to self-renewing economies. Economic Development Commentary, 5, 19-23.

Shchedrovitsky, G.P. (1981). Systems-structural research and development: principles and general framework, General Systems Vol. XXVII (1982) (translation by A. Rapoport of 'Printsipy i obshchaya skhema metodologicheskoy organizatsii sistemno-strukturnykh issledovaniy i razrabotok' [Systems research: methodological problems], Yearbook 1981, Moscow, 1981) (also published in Systems Research, Vol. II: Methodological Problems, ed. JM Gvishiani, Pergamon Press, 1985).

Solosina, M.I. (2019). Strategic planning at the municipal level: the process, analysis tools and organizational mechanisms: thesis for the degree of candidate. econ. sciences. CEMI RAS, Moscow. (In Russ.)

Solosina, M.I., \& Schepina, I.N. (2016) Strategic approach to development management at the municipal level: methodology for the analysis of settlements; approaches to developing strategies. Financial Analytics: Problems and Solutions, 48, 19-33. (In Russ.)

Tiebout, C. (1956). A Pure Theory of Local Expenditures, Journal of Political Economy, 64(5), 416-424.

Tyurin, G.V. (2007). The experience of the revival of Russian villages. Moscow: Generation, 240. (In Russ.)

Vagin, V.V. (2016). Proactive Budgeting: A Development Strategy. The Second All-Russian Conference on Proactive Budgeting. Financial magazine. Scientific and Practical Publication, 6, 129. (In Russ.)

World Development Report 2009: Reshaping Economic Geography. Retrieved from https://openknowledge.worldbank.org/handle/10986/5991

Zubarevich, N.V. (2010). Regions of Russia: inequality, crisis, modernization. Moscow: Independent Institute for Social Policy, 160. (In Russ.) 


\section{Information about the authors}

Maria I. Solosina - Phd. in Economics, Leading Engineer of Interfaculty Research Laboratory of Economics and Management (Khusulnova st. 40, 394068, Voronezh, Russia); e-mail: maria.solosina@gmail.com

Irina N. Shchepina - Doctor of Economic Sciences, Professor of Informational Technology and Mathematical Methods in Economy Department (Khusulnova st. 40, 394068, Voronezh, Russia); chief researcher, Central Economics and mathematics Institute Russian Academy of Sciences (117418, Moscow, Nakhimovsky pr. 47); e-mail: shchepina@mail.ru

ARTICLE INFO: received January 24, 2020; accepted May 6, 2020

\section{Информация об авторах}

Солосина Мария Игоревна - кандидат экономических наук, ведущий инженер межфакультетской научно-исследовательской лаборатории экономики и управления Воронежского государственного университета (394068, Россия, Воронеж, ул. Хользунова, 40); e-mail: maria.solosina@gmail.com

Щепина Ирина Наумовна - доктор экономических наук, профессор кафедры информационных технологий и математических методов в экономике Воронежского государственного университета (394068, Россия, Воронеж, Воронежская обл., ул. Хользунова, 40); главный научный сотрудник ЦЭМИ РАН (117418, Россия, Москва, Нахимовский пр., 47); e-mail: shchepina@mail.ru

ИНФОРМАЦИЯ О СТАТЬЕ: дата поступления 24 января 2020 г.; дата принятия к печати 6 мая 2020 г. 